\title{
MANDATORY COST AND OTHER COST COMING FROM THE ADOPTION OF QUALITY CERTIFICATIONS IN THE HOSPITALITY BUSINESS
}

\author{
M. Victoria Sánchez Rebull \\ Ana Beatriz Hernández \\ Lucia Banchieri \\ Fernando Campa Planas \\ Matias Ginieis
}

UDC 640.4(460)

Review

Received 12 December 2010

Revised 3 March 2011

16 April 2011

\begin{abstract}
The adaptation to the regulation of hospitality business implies a relevant cost in the profit and loss account. Additionally, some companies in this business decide to add some voluntary quality and environmental certification systems, which also yields to increased costs. The purpose of this paper is to quantify these costs and to analyse if the hotel size influences them. A total of 67 different costs were considered in hotels of all sizes, in the region of Catalonia as one of the most relevant touristic markets in Europe. Data were collected from the regulation applied to the hospitality sector, from specialised consultant companies and from a questionnaire supplied to 472 hotels in August and September 2008. The main results of this study show that the unitary cost by room, considering both, compulsory and voluntary costs, is lower in big hotels. On the other side, the smaller hotels are suffering high unitary costs. These results could be useful for the strategic orientation of hotels due to the relevance of costs to determine the competitive position of a firm. The main contribution of this work is to analyse the effects of compulsory costs and voluntary cost derived from the implementation of quality and environmental certifications in the hospitality sector, which could strongly affect the performance of this industry.
\end{abstract}

Keywords Mandatory Cost, Voluntary Cost, Quality and Environmental Certification, Firm Size, Hospitality Sector

\section{INTRODUCTION}

Spain's attraction as a tourist destination has been amply demonstrated. Taxing the tourist sector has also become a very attractive instrument for fiscal reform (Fujii et al., 1985) as well as for increasing income to finance new public expenditures. However, these taxes are frequently only applied to tourists who are not residents of the region in which they pay the tax (Gago, et al., 2009).

\footnotetext{
* The authors would like to express their gratitude for the financial support of the Directorate General for Tourism of the Government of Catalonia in Spain for this project. At the same time, they would like to extend their thanks to the Salou, Cambrils and Costa Daurada Hotel Association and the URV Scientific and Technology Park for Tourism and Leisure.

This research has been supported by General Department of Tourism of the Government of Catalonia.
} 
Tourism and Hospitality Management, Vol. 17, No. 1, pp. 153-169, 2011

M. V. Sánchez Rebull, A. B. Hernández, L. Banchieri, F. Campa Planas, M. Ginieis: MANDATORY ...

Nevertheless, the multitude of regulations which support businesses in the tourist sector should also be taken into consideration. Particularly, changes in European directives that affect national regulation in the tourism sector. These seldom improve profitability of companies in the sector and these additional costs are generally not distributed evenly among the different business in the sector.

It is precisely for this reason that the current economic situation does not bode well for profitability in the short term. The purpose of this paper is to study how these costs affect the profitability of hotels of different sizes as well as other variables in the hotel sector. This is based on the conviction that these costs are excessive and that the combined cost represents a very significant expenditure. In the case of voluntary costs (basically meaning quality certifications) these would represent a true barrier to entering the market (Garcés et al., 2004). So, the main question that this paper wishes to address is whether compulsory costs from regulation and those taken on voluntarily by hotels for quality certification affect the profitability of hotels of different sizes differently. In order to answer this question, an exhaustive study has been undertaken to identify, classify and analyse costs in order to determine per-room costs and to compare their effect on income.

The study was conducted in the Autonomous Community of Catalonia due to the prominent role it has in Spanish tourism. Catalonia is located in the North East of Spain, and occupies an area of $32,107 \mathrm{~km} 2$. It is the most important tourist destination in Spain. Nearly 7,500,000 inhabitants were recorded in the last census taken in 2009. Per capita GDP was $€ 28,046$ (www.gencat.cat). Catalonia is divided into four geographic areas called counties. Three of these are found on the coast: Barcelona, Girona and Tarragona; and the fourth, Lleida, is in the interior. Catalonia is also one of the most important tourist destinations in the world; alone it accounts for $2 \%$ of global tourism. Its geographical location, Mediterranean climate, easy access via different modes of transport, and the abundant tourist facilities make it a very attractive tourist destination. Tourism is also one of the most important sectors of the economy in Catalonia, accounting for $11 \%$ of GDP. Catalonia receives approximately 27 million tourists a year and tourism-related jobs make up $12 \%$ of total employment. Therefore, tourism is one of Catalonia's top strategic priorities.

Hotels are the most important sector in Catalonia's tourism industry. Catalan hotel groups compete in the global market and account for a very considerable portion of GDP. The most accurate current data indicates that the Catalan hotel sector (this includes restaurants as well) is responsible for more than $7 \%$ of annual GDP. However, a downturn in growth of demand in the Catalan hotel sector over the last few years has affected profitability in both economic as well as financial terms.

The background for this study traces back to the beginning of 2005, when the PIMEC (Patronal de las Micro, Pequeñas y Medianas Empresas de Cataluña - the Catalan Association of Micro, Small and Medium-sized Enterprises) and the Salou-CambrilsLa Pineda Hotel Association drafted a document on compulsory costs, the regulations that created them, and voluntary costs which some establishments assume in order to obtain certain quality systems and certifications. The study was conducted with threestar hotels and some thirty different costs were measured. A great deal of interest has 
Tourism and Hospitality Management, Vol. 17, No. 1, pp. 153-169, 2011

M. V. Sánchez Rebull, A. B. Hernández, L. Banchieri, F. Campa Planas, M. Ginieis: MANDATORY ...

been demonstrated for this study both on behalf of the Government of Catalonia and the tourism industry.

The study is structured into a total of six sections. The following section examines the theoretical model for SME costs in the hotel sector. Later, in section 3 the methods used to conduct the study are described: section 3.4 lists the sources of data; section 4 examines the results of the study; and in section 5, the conclusions drawn from the study are presented as well as possible future lines of research suggested by the study. Finally, section 6 holds the bibliography and lists reference materials.

\section{BACKGROUND}

\subsection{Costs in the hotel sector}

This study does not examine the fiscal or environmental efficacy of the aforementioned taxes, their economic implications for the distribution of business activity in the territories, or their impact on the labour market. These have already been covered in other studies on direct taxes, such as the Balearic Islands' Ecotax (Palmer and Riera, 2003).

Some studies (Martínez and Martínez, 2008) have analysed the relationship between implementing quality management systems, specifically ISO 9000, and different variables related to income or internal and external results. This has confirmed a positive relationship between regulations and internal variables. Other studies have analysed the relationship of internal variables (e.g. size) and efficacy of implementation (Brown et al., 1998). There is little data on the fiscal effects of compulsory taxes applied in the hotel sector. However, several authors have studied the relationship between quality and environmental systems and certification and profitability (Watson et al., 2004; Corbett et al., 2005; Nicolau and Sellers, 2003; Claver et al., 2010).

The competitive advantage provided by ISO certification has lessened over the years, whereas once it may have been an advantage, now it might be considered a basic requirement or possibly even a disadvantage if a business is not certified (Martínez and Martínez, 2008). Certification is proportionally more costly for small businesses (Taylor, 1995; Gustafsson et al., 2001) although there is not a great deal of evidence for this in the literature. This certification also tends to disappoint in terms of its benefit to productivity and its effect on expected costs, especially in small businesses (Rodríguez and González, 2004). From the moment the ISO norm was originally created publications began to appear, most of them were descriptive, studying businesses' motivation for implementing ISO norms, its advantages and drawbacks and its effect on profitability (Rayner and Porter, 1991).

A strong argument is made in the literature on the potential relationship between compliance and the environmental and economic benefits companies in the tourism sector derive from this, and the hypothesis that it is in the best interest of companies in the sector to be "green", although the literature is frequently not unanimous (White et al., 2009). The benefits and costs from adopting environmental measures are also not 
Tourism and Hospitality Management, Vol. 17, No. 1, pp. 153-169, 2011

M. V. Sánchez Rebull, A. B. Hernández, L. Banchieri, F. Campa Planas, M. Ginieis: MANDATORY ...

homogenous when different sectors are compared (Khanna, 2001). The market's response to companies that adopt these environmentally responsible measures is weak (Clarkson et al., 2004; Yamahita et al., 1999), although the concept of "tax exportability" may be applicable to these costs, especially when these are environmental taxes (Gago and Labandeira, 2001). However, there is indeed evidence from a legislative/contractual point of view on the negative repercussions on prices of a failure to establish hotel quality measures (Bech, 2010).

Therefore, this paper will focus on differentiating costs generated by norms and certifications by hotel size in the sector. Our approach focuses on determining if there are considerable differences in the repercussions of the costs of these norms and certifications in the cost of hotel rooms of different categories or sizes.

\subsection{SMEs in the hotel sector}

The tourism sector is indirectly responsible for $11 \%$ of European Community GDP and for $12 \%$ of employment in the region. These figures coincide with those for Catalonia. SMEs play a pivotal role in the structure of European tourism (EU, 2010), however there have been few studies on them (Page et al., 1999; Ateljevic, 2007)

The Catalan hotel industry's is comprised of primarily micro and small businesses which make up $88.2 \%$ of total businesses in the sector. This percentage also coincides with data for Europe, where approximately $90 \%$ of hotels are SMEs (Bastakis et al., 2004). Recently there has been a reduction in the number of Catalan hotels. This reduction took place among the micro-businesses, while other hotel sizes saw increases. The increase was concentrated in the higher category hotels, although a certain amount of renovation and improvement also took place as well as a reinforcement of the luxury hotel boom.

SMEs are a key element of the regions' economies because they contribute greatly towards generating employment and other wealth which promotes economic welfare. On the other hand, they also very adept at able at adapting to dynamic situations, which helps them to survive (Page et al., 1999). These types of business also have several weaknesses: less negotiating power, a lack of planning and strategic vision, and problems with marketing (Bastakis et al., 2004). Another issue with SMEs discovered by Almeida et al., (2009) is the elevated cost for SMEs to adopt quality control systems.

In order to combat these weaknesses, the European Union has tried to provide SMEs in the tourism sector with tools which can improve profitability and strengthen competitiveness so that these businesses can contribute to sustainable development, create employment and generate wealth (EU, 2010).

In light of what has been covered here so far, we believe that a deeper examination of the relationship between profitability, the implementation of quality certifications, and compliance with compulsory norms in the hotel sector would indeed fill a gap that currently exists in the research to date, and that it would be of interest both from an academic and professional standpoint. 
Tourism and Hospitality Management, Vol. 17, No. 1, pp. 153-169, 2011

M. V. Sánchez Rebull, A. B. Hernández, L. Banchieri, F. Campa Planas, M. Ginieis: MANDATORY ...

\section{METHODS EMPLOYED IN THE STUDY}

\subsection{Objectives of the study}

This study aims to address the question of how compulsory regulatory costs and costs related to voluntarily adopting quality certifications affect the profitability of hotels of different sizes. In order to answer this question, we have established three objectives. Firstly, it is important to know the per-room cost derived from norms applied in the hotel sector and voluntarily costs assumed by hotels in order to satisfy clients' demands for quality certification. Secondly, this study aims to determine the effect of these norms on fiscal variables. And thirdly, the study compares the repercussion of these norms by county and hotel size in order to determine if hotel size has an influence in making the impact of these greater or lesser in relative terms.

In an economic climate of decelerating growth in the hotel sector, this work takes on greater relevance and interest for the tourist sector. This is demonstrated by the support received to conduct this study. Having this information available will help to shed light on the negative economic effects of smaller hotels assuming these costs, which discourages voluntary environmental and quality certifications by these same hotels. This is also an excellent opportunity to assist with the creation of a model to simplify regulations, or possibly even to create wholly a unique regulatory structure. The Bolkestein Directive, a directive which aims to simplify administrative procedures for service businesses, and which was approved by the European Commission and based on the European Community Treaty, went into effect in 2006. This directive is not itself a simplification of the norms as we have stated, but it does represent a considerable advance in reducing paperwork for these businesses.

\subsection{Unit of analysis}

The unit of analysis that we chose was hotels located in the Autonomous Community of Catalonia. Catalonia was chosen for the pivotal role the sector plays in Catalonia's economy; because Catalonia is the primary tourist destination in Spain; and because it is one of the regions in which the greatest number of hotels that have "Q" quality certification (Catalonia is third after Andalucia and the Valencian Community).

\subsection{Calculation of per-room cost}

Figure 1 shows the procedure used to determine costs derived from regulations and voluntary certification and establishes a "standard" hotel so that per-room cost can be calculated.

\footnotetext{
${ }^{1} \mathrm{Q}$ is the symbol representing quality in the Spanish hotel sector. This distinction is awarded by the Institute for Spanish Tourism Quality. In order to receive this certification, hotel establishments must pass strict quality controls that ensure that high-quality, safe and professional services are provided.
} 
Tourism and Hospitality Management, Vol. 17, No. 1, pp. 153-169, 2011

M. V. Sánchez Rebull, A. B. Hernández, L. Banchieri, F. Campa Planas, M. Ginieis: MANDATORY ...

Figure 1: Calculation of cost per room

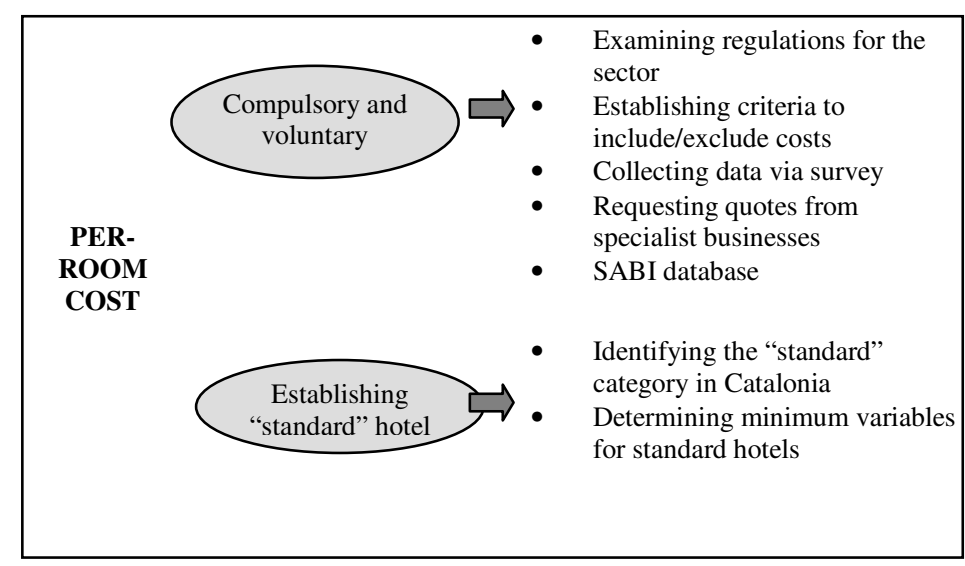

Source: created by the authors of this paper

In order to classify compulsory and voluntary costs and to determine what part of these costs were due to regulations 67 different types of costs were examined. The five phases involved in the determination of compulsory and voluntary costs are as follows.

Phase 1: An exhaustive study of regulations applicable to the sector was conducted. For this phase, we were able to rely on the professional advice and consulting services of the Salou-Cambrils-La Pineda Hotel Association. In phase one we also studied compulsory costs and costs related to the voluntary acquisition of certain certifications or implementation of systems, generally done to satisfy the demands of the market in which the hotels operate, which, classified by size, must also cover operational costs.

Phase 2: Costs to be considered in the study were determined. Businesses in this sector have a great deal of costs, some of these stem directly from the business activity itself or financing, while others are from the application of different norms. In order to determine which costs should be included in the study, we considered the following criteria:

- Exclusivity: Compulsory costs that are specifically and exclusively related to this sector. This would not include, for example, the Impuesto de Bienes Inmuebles (the IBI, the tax on immovable assets, i.e. Spanish equivalent of the land value tax, or site value tax), rubbish removal fees, fees for "no parking" areas, insurance, vehicle taxes and other taxes from municipal ordinances, etc. as well as voluntary costs that only affect this sector or which may be applied in other sectors, but which are clearly costs which apply to the hotel sector, such as the implementation of EcoManagement and Audit Scheme (EMAS) or ISO norms. Therefore this does not include the VAT tax applied in more than 130 countries and in almost all transactions which take place in all sectors of the economy.

- Reliability and standardisation: Voluntary and compulsory costs whose amounts can be reliably determined or standardised. From this it can be determined that the costs must correspond to services provided by external companies and in no case from a determination based on the number of hours dedicated by internal personnel 
Tourism and Hospitality Management, Vol. 17, No. 1, pp. 153-169, 2011

M. V. Sánchez Rebull, A. B. Hernández, L. Banchieri, F. Campa Planas, M. Ginieis: MANDATORY ...

to certain tasks like maintenance of hydro-massage bathtubs, Jacuzzis, temperature controlled swimming pools, etc., i.e. costs which would be difficult to homogenise or find an average for in the sector.

- Discretion: Costs that do not depend exclusively on internal decisions of the companies themselves, such as costs from the application of the Spanish Tobacco Law (LAW 28/2005 on the selling, distributing, consumption and publicity on tobacco).

- Universitality: Costs borne by hotels throughout Catalonia regardless of the negotiating policies or capacity of the business, such as costs covered by suppliers in certain purchase arrangements or for the transport of these products.

- Relative importance: Costs that are for very small purchases such as signs, plaques, etc. have not been included.

However, costs derived from compulsory regulation and costs assumed voluntarily have been included separately because it would be impossible to calculate these together. These costs have been classified into the two following categories (see tables 1 and 2):

- Periodic costs: These are costs that are incurred repeatedly by the hotels. These costs are calculated per year with a periodicity of more than one year for comparative and calculation purposes.

- Non-periodic costs: These are generally costs related to the implementation or initial adaptation of norms or certifications which are generally only done once, for example, the implementation and creation of a Hazard Analysis Critical Control Point or HACCP system or environmental quality certification.

The study was done based on these criteria and includes a total of 55 compulsory costs and 12 voluntary ones.

Table 1: Voluntary costs

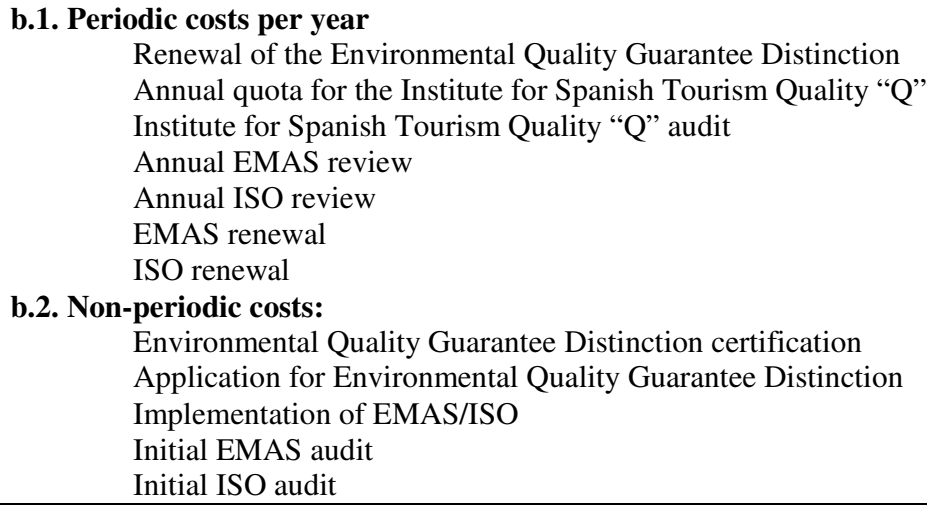

Source: created by the authors of this paper. 
Tourism and Hospitality Management, Vol. 17, No. 1, pp. 153-169, 2011

M. V. Sánchez Rebull, A. B. Hernández, L. Banchieri, F. Campa Planas, M. Ginieis: MANDATORY ...

Phase 3: A survey was distributed via regular mail and this was then followed up by telephone. The survey is technical in nature and solicited information from individuals directly responsible for handling business expenditures, as well as information on the administration of accounting data and the implementation of the different norms.

Table 2: Compulsory costs

\section{a.1. Periodic costs per year}

Elevator inspection (price per elevator)

Low tension inspection

Acoustic measures check

Restaurant and food product health inspection

Health inspection: restaurant potable water

Public swimming pool inspection

Legionnaires disease risk inspection

Legionnaires disease preventative analysis inspection

Inspection of refrigeration towers

Legionnaires disease hot and cold water analysis

Legionnaires disease Jacuzzi analysis

Legionnaires disease fire-fighting water analysis

Legionnaires disease waste water analysis

Legionnaires disease preventative maintenance plan for refrigeration towers

Legionnaires disease preventative maintenance plan for hot and cold water systems

Legionnaires disease preventative maintenance plan for Jacuzzis

Legionnaires disease preventative maintenance for fire-fighting water systems

Cleaning and disinfection of refrigeration towers

Cleaning and disinfection cold and hot water cisterns

Cleaning and disinfection of Jacuzzis

Cleaning and disinfection of the fire-fighting water system

Cleaning and disinfection of cisterns

Revision of refrigeration towers/condensers

Revision of hot and cold water systems

Revision of Jacuzzi

Revision of fire-fighting water system

Revision of propane or natural (city) gas system

ECA verification

Rodent control and disinfection

Workplace hazard prevention, technical verification

Workplace hazard prevention, health inspection

Periodic environmental action inspection

Periodic fire prevention action inspection

Data protection maintenance

a.2. Non-periodic costs:

HACCP system implementation

HACCP line creation supplement

Implementation and creation of self-regulating plan for swimming pools for public use Implementation of self-regulating Legionnaires disease plan

Maintenance personnel training for Legionnaires disease facilities

Adaptation of environmental evaluation model

Verification of environmental evaluation

Initial environmental inspection/certification

Initial quota for data protection

Technical certification

Initial swimming pool inspection 
Tourism and Hospitality Management, Vol. 17, No. 1, pp. 153-169, 2011

M. V. Sánchez Rebull, A. B. Hernández, L. Banchieri, F. Campa Planas, M. Ginieis: MANDATORY ...

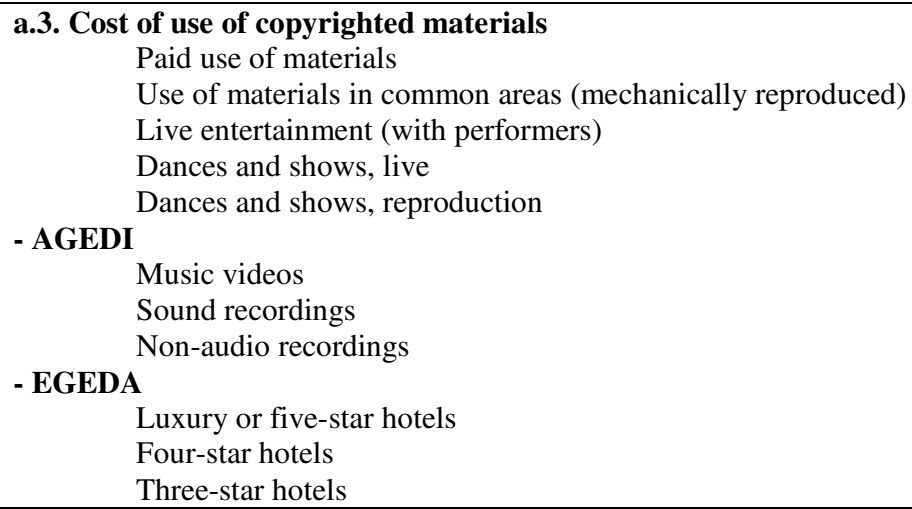

Table 3: Technical data for the study

\begin{tabular}{|l|l|}
\hline Universe & All hotels in Catalonia \\
\hline Geographic area & Catalonia \\
\hline Data collection method & Semi-structured survey \\
\hline Sample procedure & Categorised by county and hotel size \\
\hline Sample size & 472 surveys \\
\hline Valid responses & $9.7 \%$ \\
\hline Sample error & $5 \%$ \\
\hline $\begin{array}{l}\text { Period in which fieldwork was } \\
\text { conducted }\end{array}$ & August to September 2008 \\
\hline
\end{tabular}

Source: created by the authors of this paper.

The sample is categorised by county and size and consists of 472 hotels distributed throughout the four Catalan counties (Lleida, 64; Tarragona, 79; Girona, 137; and Barcelona, 192). The sample size is sufficiently large for the data collected for the study, with a margin of error of 5\%. Fieldwork was conducted from 15 August to 15 September 2008. It should be noted that the level of response was not excessively high, around $10 \%$ (table 3 ). One reason for this may be that since this was a technical survey a response would often involve the participation of different departments, especially in the case of larger hotels.

Phase 4: Quotes were requested from specialist businesses - some of which were specially licensed - for costs which could not be determined from the regulations or the survey.

The majority of costs studied were specified according to size hotel size, which were initially categorised by number of rooms (up to 30, 50, 150, 250 and 500). However, for this study, and in order to simplify the categories, the data has been categorised into hotels of up to 30, 150 and 500 rooms, which correspond to small, medium and large hotels. Other costs, such as those derived from copyrighted materials, such as SGAE, AGEDI, and EGEDA are classified according to hotel rating, since it would be impossible to classify them by hotel size. Obviously, some costs are related to the 
Tourism and Hospitality Management, Vol. 17, No. 1, pp. 153-169, 2011

M. V. Sánchez Rebull, A. B. Hernández, L. Banchieri, F. Campa Planas, M. Ginieis: MANDATORY ...

presence of certain facilities, such as swimming pools, hydro-massage baths, Jacuzzis, restaurants, etc.

Phase 5: Data required for the study of the impact of the aforementioned costs is stated in both absolute and relative values, compared to, for example, the turnover of hotels of different sizes. Economic data for the sector was obtained from SABI (Sistema de Análisis de Balances Ibéricos - Iberian Balance Sheet Analysis System).

It was necessary to determine the most representative type of hotel, or the "standard" hotel in the Catalonian region in order to subsequently perform the corresponding calculations. According to the Directorate General for Tourism in Catalonia, the most common type of hotel in Catalonia is the three-star hotel. So, for the purposes of the study, the three-star hotel used as the standard, with the assumption that the hotel chose to adopt quality certifications, has a pool, certified power of between 20 and $50 \mathrm{kw}$, a Jacuzzi, a cistern, and that annually two food inspections, twelve samples (one for each inspection) and one annual elevator review were conducted.

\subsection{Data sources}

Data used for this study is from 2008 and has been obtained from the following sources:

- Prices and/rates that are stipulated by current legislation, for example, rates to be applied by inspection and control agencies (EIC- Entitats d'Inspecció i Control Control and Inspection Agencies) of the Government of Catalonia for safety, quality and industrial regulation.

- Based on quotes obtained from specialist businesses - some with special licences for costs from the provision of services, such as implementation and auditing of EMAS systems or Institute for Spanish Tourism Quality certifications.

- Data from the aforementioned survey distributed to the hotels. From this important data on average costs borne by the hotels of different sizes was obtained that otherwise could not have been obtained from other sources.

- Economic and accounting data was obtained from SABI (the Sistema de Análisis de Balances Ibéricos, or Iberian Balance Sheet Analysis System). Accounting data was also obtained from some hotels using the USALI (Uniform System of Accounts for Lodging Industry) system which provides detailed information by hotel department (Campa and Sánchez, 2008). This system was chosen in order to obtain homogenous data for the population analysed.

\section{RESULTS}

In order to meet the first objective of this paper, the total and per-room costs derived from the aforementioned compulsory and voluntary costs were quantified. In this study, for purposes of simplification, hotels have been categorised into small, medium and large hotels (30, 150 and 500 rooms). 
Tourism and Hospitality Management, Vol. 17, No. 1, pp. 153-169, 2011

M. V. Sánchez Rebull, A. B. Hernández, L. Banchieri, F. Campa Planas, M. Ginieis: MANDATORY ...

The calculations indicate that the standard hotel (three-star) used as a reference, with an average of 150 rooms, would bear a total annual cost (compulsory and voluntary) of approximately $€ 38,384$, €30,185€ of which is attributable to compulsory costs and $€ 8,199$ of which is attributable to voluntary costs (Table 4), which, as we will see, is equivalent to $2.14 \%$ of turnover. In the initial year in which they are assumed, these costs can reach $€ 64,336$ in the first year ( $€ 38,436$ compulsory, and $€ 25,900$ voluntary) which represents $3.58 \%$ percent of turnover.

Table 4: Annual compulsory and voluntary costs by hotel size $2008(€)$

\begin{tabular}{|l||c|c|c|}
\hline & 30 Hab. & 150 Hab. & 500 Hab. \\
\hline Obligatorios & $20.177,72$ & $30.184,86$ & $45.930,76$ \\
\hline Voluntarios & $5.595,73$ & $8.199,48$ & $9.322,43$ \\
\hline Total & $\mathbf{2 5 . 7 7 3 , 4 5}$ & $\mathbf{3 8 . 3 8 4 , 3 4}$ & $\mathbf{5 5 . 2 5 3 , 1 9}$ \\
\hline
\end{tabular}

Source: created by the authors of this paper.

The amount of these costs in absolute terms according to hotel size (Table 1) which each hotel assumes annually does not increase proportionally with the number of rooms. A hotel with 30 rooms assumes $€ 25,773$ in compulsory and voluntary costs annually, while a hotel with 500 rooms must pay approximately twice as much.

Similarly, it seems that the initial costs assumed by each hotel in the implementation of regulations and certification systems (Table 4) do not increase proportionally with hotel size. These represent costs that we believe could only be passed on in price with some difficulty (tax exportability). It was observed that the smaller hotels had greater difficulties meeting these costs. Implementing the regulations and certifications cost $€ 20,326$ for a hotel with 30 rooms, while a hotel with 500 rooms paid only $30 \%$ of this cost (Table 5)

Table 5: Compulsory and voluntary costs for initial implementation of regulations and certification systems 2008 (€)

\begin{tabular}{|l|c||c|c|}
\hline Costs & $\mathbf{3 0}$ Room. & $\mathbf{1 5 0}$ Room. & 500 Room. \\
\hline Compulsory & $6.393,20$ & $8.251,50$ & $9.186,50$ \\
\hline Voluntary & $13.932,97$ & $17.700,97$ & $18.468,97$ \\
\hline Total & $\mathbf{2 0 . 3 2 6 , 1 7}$ & $\mathbf{2 5 . 9 5 2 , 4 7}$ & $\mathbf{2 7 . 6 5 5 , 4 7}$ \\
\hline
\end{tabular}

Source: created by the authors of this paper.

Per-room cost related to initial implementation also decreases as hotel size increases. For a hotel with 30 rooms the per-room cost for the items under study was $€ 678$, while a hotel with 500 rooms paid only $€ 55$, a twelfth of the cost for the 30-room hotel (Table $6)$. 
Tourism and Hospitality Management, Vol. 17, No. 1, pp. 153-169, 2011

M. V. Sánchez Rebull, A. B. Hernández, L. Banchieri, F. Campa Planas, M. Ginieis: MANDATORY ...

Table 6: Per-room and per-year cost for initial implementation of (compulsory and voluntary) regulations and certification systems by hotel size 2008 (€)

\begin{tabular}{|l|c|c|c|}
\hline Costs & $\mathbf{3 0}$ Room & $\mathbf{1 5 0}$ Room & $\mathbf{5 0 0}$ Room \\
\hline Compulsory & 213,11 & 55,01 & 18,37 \\
\hline Voluntary & 464,43 & 118,01 & 36,94 \\
\hline Total & $\mathbf{6 7 7 , 5 4}$ & $\mathbf{1 7 3 , 0 2}$ & $\mathbf{5 5 , 3 1}$ \\
\hline
\end{tabular}

Source: created by the authors of this paper.

If this same analysis was performed by adding up recurrent costs and costs for initial implementation in the first year, and with more hotel size classifications, there is a marked decrease in both types of costs (compulsory and voluntary) for large hotels (Fig. 2).

Figure 2: Total per-room compulsory and voluntary periodic costs $(€)$.

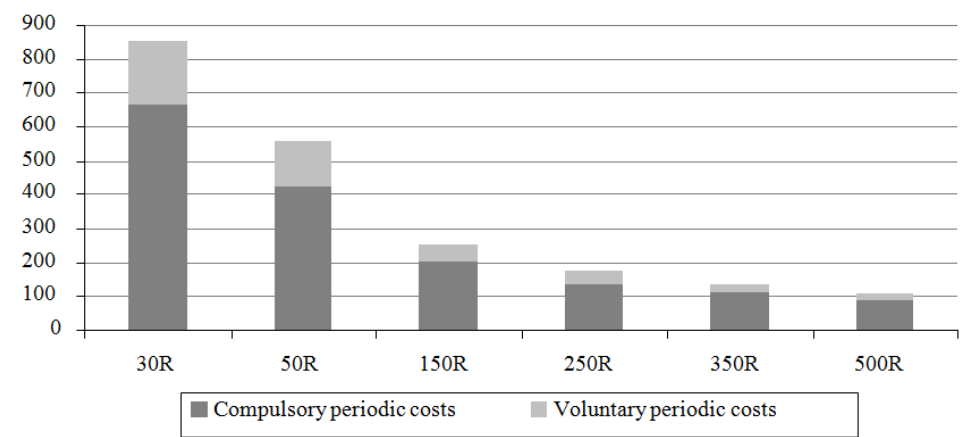

Source: created by the authors of this paper.

The second stated objective of this paper was to assess the impact of these costs on economic parameters of the hotels (basically turnover and operating costs). In small businesses, compulsory costs in small businesses represented $5.72 \%$ of turnover. The sum of compulsory and voluntary cost was $7.31 \%$, while in the larger hotels this was only $0.22 \%$. The tendency is for these costs to increase year over year as new regulations are introduced, or simply as current regulations are amended. This indicates that the competitiveness of small hotels will clearly be negatively affected, which in turn will lead to a situation in which it will be increasingly difficult for small businesses to implement quality certifications. (Table 7).

Table 7: Periodic costs as a percent of hotel turnover by size 2008

\begin{tabular}{|l|c|c|c|}
\hline Costs & $\mathbf{3 0}$ Room & $\mathbf{1 5 0}$ Room & $\mathbf{5 0 0}$ Room \\
\hline Compulsory & $5,72 \%$ & $1,68 \%$ & $0,18 \%$ \\
\hline Voluntary & $1,59 \%$ & $0,46 \%$ & $0,04 \%$ \\
\hline Total & $\mathbf{7 , 3 1 \%}$ & $\mathbf{2 , 1 4 \%}$ & $\mathbf{0 , 2 2 \%}$ \\
\hline
\end{tabular}

Source: created by the authors of this paper. 
Tourism and Hospitality Management, Vol. 17, No. 1, pp. 153-169, 2011

M. V. Sánchez Rebull, A. B. Hernández, L. Banchieri, F. Campa Planas, M. Ginieis: MANDATORY ...

This analysis is for the third objective of this paper, i.e. determining and comparing the impact of these costs, separately and jointly, in the income statements of these hotels by county. Girona and Lleida are the counties in which these costs were the greatest in terms of percentage of turnover $(6.56 \%$ and $5.63 \%)$. The standard hotel type in Lleida is the 2-star hotel, i.e. with less than 50 rooms, while the most common hotel type in Girona and Barcelona is the 3-star hotel, i.e. with less than 150 rooms. The impact of these costs in Tarragona and Barcelona was considerably less, although, it should be noted that the average hotel in Tarragona is a 3-star hotel with less than 250 rooms. The average for Catalonia was $1.68 \%$ for compulsory costs and $0.46 \%$ for voluntary costs as a percent of turnover. (Fig. 3).

Figure 3: Impact of periodic compulsory and voluntary costs as a percentage of turnover

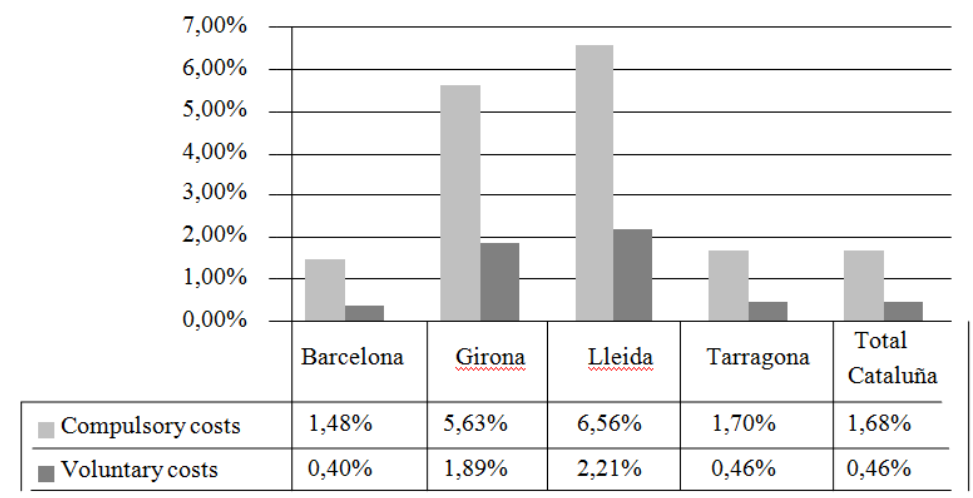

Source: created by the authors of this paper.

The analysis also revealed considerable differences in operating costs from county to county: In a hotel in Lleida the costs arising from regulatory or certification systems represented $13.40 \%$ of operating costs. In Barcelona, this same cost was only $3.14 \%$, and the average for Catalonia was $3.47 \%$ (Fig. 4).

Figure 4: Impact of compulsory and voluntary costs on operating costs by county

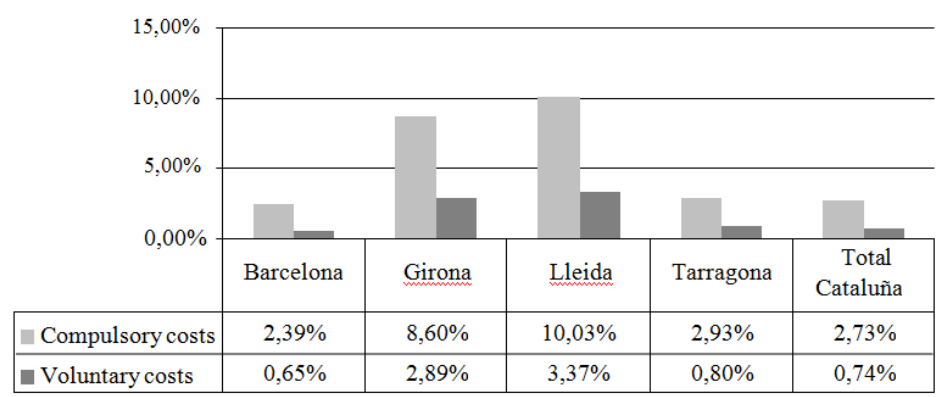

Source: created by the authors of this paper. 
Tourism and Hospitality Management, Vol. 17, No. 1, pp. 153-169, 2011

M. V. Sánchez Rebull, A. B. Hernández, L. Banchieri, F. Campa Planas, M. Ginieis: MANDATORY ...

Finally, it is noteworthy that certain quality labels included in this paper as voluntary certifications, such as the Environmental Quality Guarantee Distinction or the EMAS Eco-Management and Audit Scheme are oriented towards recognising compliance with certain good practices which should lead to environmental sustainability and that could be described as suitable measures in the arena of sustainable tourism. Businesses must assume different costs for these certificates, for example, the cost of periodic environmental inspections, reports, the Environmental Quality Guarantee Distinction, annual quotas, implantation of the systems, maintenance, and audits of the certificates. So, environmental measures cost money. In general, according to the answers obtained from the survey: $9.3 \%$ of hotels have implemented EMAS/ISO; 21.6\%, the Environmental Quality Guarantee Distinction; and 20.9\%, the quality Q (Sanchez et al., 2008), whereas in 2006 only 4.09\% of hotels had Q certification, $2.23 \%$ had ISO 9001, and almost no hotels had adopted ISO 14001 or good environmental practices.

\section{CONCLUSIONS}

Our study aims to quantify compulsory costs that hotels must bear which stem from current regulation which applies particularly to this sector and voluntary costs related to certifications and systems which are orientated more towards quality management. This quantification helps to shed light on the financial impact of these costs on hotels and on per-room costs and to establish if the hotel size increases or decreases this impact in relative terms in the four counties of Catalonia.

One of the most important conclusions of the study is that the data reveals an inverse relationship between hotel size (measured in number of rooms) and the per-room cost from regulations imposed on the sector and voluntary certification systems.

The data obtained shows that in the first year of implementation of these regulations and other voluntary costs, a hotel with 30 rooms pays costs of $€ 677.54$ annually per room (obligatory and voluntary), whereas a hotel of 500 rooms pays only $€ 55.31$ per room. This reduction is apparent in both the compulsory and voluntary price categories. For all subsequent years after the initial implementation the total price declines to $€ 672.59$ annually per room in 30-room hotels, and €91.56 in 500-room hotels. In relative terms, therefore, micro and small hotels bear costs that are far higher than those of large hotels, a fact which may condition their future development and the development of the sector.

Costs from compulsory regulation represent a considerable part of total hotel costs, reaching $7.54 \%$ of turnover in small hotels. Furthermore, the general trend in for these costs is continued growth and it is also difficult to pass these costs on through pricing.

The data confirms that small and medium businesses suffer the most under this system. It is very likely that reducing obligatory costs would encourage to more businesses to implement voluntary quality certificates such as the quality Q. In general, hotels lack sufficient capacity and resources to comply with voluntary certificates. This effect is yet more pronounced in certain counties, such as Lleida and Girona, which are well above the average for Catalonia. 
Tourism and Hospitality Management, Vol. 17, No. 1, pp. 153-169, 2011

M. V. Sánchez Rebull, A. B. Hernández, L. Banchieri, F. Campa Planas, M. Ginieis: MANDATORY ...

This paper also examined voluntary certifications of good environmental practices, such as the Environmental Quality Guarantee Distinction or the EMAS EcoManagement and Audit Scheme. Although the level of implementation of these in the hotels was not very high, they are presented as measures which lead to environmental sustainability and which could be construed as suitable environmental measures for sustainable tourism.

Since this study is limited to Catalonia, Spain, we believe it would of interest to expand the area of study to the entire country, and even to other European Union countries. The different tourist destinations in Europe all compete with each other. Determining if smaller tourist businesses are presented with greater difficulties than larger hotels would provide interesting information as to how to approach the application of corrective measures.

\section{REFERENCES}

Almeida, M.M., Rodríguez, J.M., Rubio, L. and Celemin, M. (2009), Organizacional impacts of quality certification on business services, An Analysis of the SMEs hotels, POMS $20^{\text {th }}$ Annual Conference Orlando, U.S.A.

Andrews, R. (1998), "Environmental regulation and business 'self-regulation”, Policy Sciences No. 31, pp. $177-197$.

Ateljeviv, J. (2007), "Small tourim firms and management practices in New Zealand: The Centre Stage Macro Region", Tourism Management, Vol. 28, No. 1, pp. 307-316.

Bastakis, C., Buhalis, D. and Butler, R.. (2004), "The perception of small and medium sized tourism accommodation providers on the impacts of the tour operators' power in Eastern Mediterranean", Tourism Management, Vol. 25, No. 2, pp. 151-170.

Bech Serrat, J.M. (2010), Quality of hotel service and consumer protection: A European contract law approach, Tourism Management, doi:10.1016/j.tourman.2010.02.003.

Blanco, E., Rey-Maquieira, J. and Lozano, J. (2009), "Economic incentives for tourism firms to undertake voluntary environmental Management", Tourism Management, No. 30, pp. 112-122.

Brown, A., Van der Wiele, T. and Loughton, K. (1998), "Smaller enterprises' experiences witb ISO 9000", International Journal of Quality \& Reliability Management, Vol. 15, No. 3, pp. 273-285.

Campa, F. (2005), La Contabilidad de gestión en la Industria Hotelera: Estudio sobre su implantación en las cadenas hoteleras en España, Tesis Doctoral, Universidad Rovira i Virgili, Reus.

Campa, F. and Sánchez, M.V. (2008), "La estructura de la cuenta de resultados de gestión en el sector hotelero", Revista Harvard Deusto, Finanzas \& Contabilidad, Noviembre/diciembre, No. 86, pp. 22-30.

Clarkson, M., Li, P. and Richardson, G.D. (2004), "The market valuation of environmental capital expenditures by pulp and paper companies", The Accounting Review, No. 79, pp. 329-353.

Claver, E., Pereira, J., Molina, J.F. and Tarí, J.J. (2010), "Certificación en calidad y medio ambiente y su relación con el rendimiento empresarial: evidencia en el sector hotelero español”, Papers de turismo, No. 47-48, pp. 25-38.

Corbett, C., Montes-Sancho, M.J. and Kirsch, D.A. (2005), "The financial impact of ISO 9000 certification in the United States: An empirical analysis", Management Science, Vol. 51, No. 7, pp. 1046-59.

Decreto 95/2000, de 22 de febrero, por el que se establecen las normas sanitarias aplicables a las piscinas de uso público-

Fujii, E., Khaled, M. and Mak, J. (1985), “The exportability of hotel occupancy and other tourist taxes", National Tax Journal, No. 38, pp. 169-177.

Gago, A. and Labandeira, X. (2001), "Turismo y fiscalidad ambiental”, Papeles de economía española, No. 87, pp. 179-186.

Gago, A., Labandeira, X., Picos, F. and Rodríguez, M. (2009), "Specific and General Taxation of Tourism Activities. Evidence from Spain”, Tourism Management, Vol. 30, No. 3, pp. 87-112.

Garcés, C., Murillo, J.L. and Rivera, P. (2004), "Estrategia empresarial y medio ambiente: opinión de un grupo de expertos", Universia Business Review, No. 4, pp. 52-63. 
Tourism and Hospitality Management, Vol. 17, No. 1, pp. 153-169, 2011

M. V. Sánchez Rebull, A. B. Hernández, L. Banchieri, F. Campa Planas, M. Ginieis: MANDATORY ...

Gustafsson, R., Klefsjö, B., Berggren E. and Wellemets U. G. (2001), "Experiences from implementing ISO 9000 in small enterprises - a study of Swedish organizations", The TQM Magazine, Vol. 13, No. 4, pp. 232-246.

Khanna, M. (2001), "Non-mandatory approaches to environmental protection", Journal of Economic Surveys, No. 15 , pp. 291-324.

Ley 31/95 de Prevención de Riesgos Laborales, de 8 de noviembre, modificada por la Ley 54/2003.

Ley 3/98, de 27 de febrero (modificada por el Real Decreto 143/2003 y la Ley 1/1999) de la intervención integral de la administración ambiental.

Ley 28/2005, de 26 de diciembre, de medidas sanitarias frente al tabaquismo y reguladora de la venta, el suministro, el consumo y la publicidad de los productos del tabaco, modificado el 23 de diciembre de 2009.

Ley Orgánica 15/1999, de 13 de diciembre, de Protección de Datos de Carácter Personal.

Martínez, M. and Martínez, A.R. (2008), "Sistemas de gestión de calidad y resultados empresariales: una justificación desde las teorías institucional y de recursos y capacidades", Cuadernos de Economía y Dirección de la Empresa, No. 34, pp. 7-30.

Nicolau, J.L. and Sellers, R. (2003), "Influencia de la calidad sobre la rentabilidad y la volatilidad" Revista de Economía Aplicada, Vol. XI, No. 33, pp. 65-82.

Organización Mundial Del Turismo (1998), La fiscalidad del turismo, OMT, Madrid.

Orden de 30 de junio de 1999, por la cual se regula el control metrológico sobre los instrumentos destinados a medir los niveles de sonido audible.

Orden de 28 de noviembre de 2000, por la cual se regula el procedimiento de actuación del Departamento de Industria, Comercio y Turismo para la aplicación del Reglamento electrotécnico para baja tensión, mediante la intervención de las entidades de inspección y control de la Generalitat de Cataluña.

Orden ICT/104/2002, 25 de marzo por la cual se actualizan las tarifas a aplicar las entidades de inspección y control (EIC) concesionarias de la Generalitat de Cataluña en el ámbito de la seguridad, calidad y normativa industriales.

Page, S.J., Forer, P. and Lawton, G.R. (1999), 2Small business development and tourism: Terra incognita?", Tourism Management, Vol. 20, No. 4, pp. 435-459.

Palmer, T. and Riera, A. (2003), "Tourism and environmental taxes with special reference to the 'Balearic ecotax", Tourism Management, No. 24, pp. 665-674.

PIMEC (2005), Repercusión económica de la normativa sobre la competitividad del sector hotelero, PIMEC, Barcelona.

Rayner, P. and Porter, LJ. (1991), "The Experience of Small and Medieum-sized Firms", International Joumal of Quality and Reliability Management, Vol. 8, No. 6, pp. 16-28.

Real Decreto 291/1991, de 11 de diciembre de instalaciones receptoras de gases combustibles.

Real Decreto 1314/1997, de 1 de agosto, sobre ascensores y mantenimiento.

Real Decreto 140/2003, de 7 de febrero, por el que se establecen los criterios sanitarios de la calidad del agua de consumo humano.

Real Decreto 865/2003, de 4 de julio, por el que se establecen los criterios higiénico-sanitarios para la prevención y control de la legionelosis.

Real Decreto 1376/2003, de 7 de noviembre, por el que se establecen las condiciones sanitarias de producción, almacenamiento y comercialización de las carnes frescas y sus derivados en los establecimientos de comercio al por menor.

Real Decreto 127/2006, de 15 de septiembre, de Prevención de la contaminación y Calidad Ambiental.

Rodríguez Escobar, J.A. and González Benito, J. (2004), "Un estudio de la insatisfacción generada por la certificación ISO9000 en la pequeña empresa. Documento de Trabajo", Nuevas Tendencias en Dirección de Empresas, Universidad de Salamanca, Vol. 11, No. 03, pp. 1-18.

SABI [Recurso electrónico]: sistema de análisis de balances ibéricos. [Consulta: 10 de noviembre de 2009], http://sabi.bvdep.com/version-20101014/cgi/template.dll?product=27\&user=ipaddress.

Sánchez, M.V. (2002), La propuesta ABC (Activity Based Costing) aplicada al sector hotelero, Tesis Doctoral, Universitat Rovira i Virgili, Reus.

Taylor, W.A. (1995), "Organizational differences in ISO 9000 implementation practices", International Journal of Quality \& Reliability Management, Vol. 12, No. 7, pp. 10-27.

Union Europea, 2010, Declaración de Madrid "Hacia un modelo turistico socialmente responsable" [online] Disponible en: http://eu2010.es/export/sites/presidencia/comun/descargas/agenda/Cultura/abr15_declaracionrimt urismo.pdf [Accedida el 18 de mayo de 2010]

Yamahita, M., Sen, S. and Roberts, M. C. (1999), "The rewards for environmental conscientiousness in the U.S. capital markets”, Journal of Financial and Strategic Decisions, Vol. 12, No. 1, pp. 73-82. 
Tourism and Hospitality Management, Vol. 17, No. 1, pp. 153-169, 2011

M. V. Sánchez Rebull, A. B. Hernández, L. Banchieri, F. Campa Planas, M. Ginieis: MANDATORY ...

Watson, K., Klingenberg, B., Polito, T. and Geurts, T. (2004), "Impact of environmental management system implementation on financial performance", Management of Environmental Quality, No. 15, pp. 622-628.

http://www.boe.es

http://www.calidadturistica.es

http://www.egeda.es

http://www.gencat.cat

http://www.idescat.es

http://www.iso.org

http://www.mtas.es

http://www.sgae.es

M. Victoria Sánchez Rebull, $\mathrm{PhD}$

Rovira i Virgili University

Department of Business Management

Av. Universitat, 1, (43204) Reus (Tarragona), Spain

e-mail: mariavictoria.sanchez@urv.cat

Ana Beatriz Hernández, $\mathrm{PhD}$

Rovira i Virgili University

Department of Business Management

Av. Universitat, 1, (43204) Reus (Tarragona), Spain

e-mail: anabeatriz.hernandez@urv.cat

Lucia Banchieri, $\mathrm{PhD}$

Rovira i Virgili University

Department of Business Management

Av. Universitat, 1, (43204) Reus (Tarragona), Spain

luciaclara.banchieri@urv.cat

Fernando Campa Planas, $\mathrm{PhD}$

Rovira i Virgili University

Department of Business Management

Av. Universitat, 1, (43204) Reus (Tarragona), Spain

e-mail: fernando.campa@urv.cat

Matias Ginieis, $\mathrm{PhD}$

Rovira i Virgili University

Department of Business Management

Av. Universitat, 1, (43204) Reus (Tarragona), Spain

e-mail: matias.ginieis@urv.cat 